\title{
PENGEMBANGAN ALTERNATIF MODEL E-PAYMENT B2C (BUSINESS TO CONSUMER)
} UNTUK MASYARAKAT INDONESIA

\author{
Agung Firmansyah, Muhammad Ilman Akbar, Mursal Rais, Mustafa Kamal, dan Putu Wuri \\ Handayani
}

Fakultas Ilmu Komputer, Universitas Indonesia, Kampus Baru UI Depok, Jawa Barat, 16424, Indonesia

E-mail: agung_ahaa@yahoo.com

\begin{abstract}
Abstrak
Saat ini, perkembangan aplikasi e-commerce di Indonesia khususnya aplikasi B2C (Business to Consumer) semakin meningkat. Salah satu komponen penting dalam proses jual beli secara online adalah proses pembayaran elektronik (e-payment). Penelitian ini bertujuan untuk mengembangkan empat model pembayaran elektronik berdasarkan kondisi ekonomi, keamanan, tingkat pendidikan, akses teknologi, pengguna telepon seluler dan pengguna kartu kredit dan ATM di Indonesia. Model pembayaran tersebut yaitu ATMPal, iCash, Pulsa E-payment dan Mobile Banking. Selain itu, dalam penelitian ini akan ditentukan peringkat kesesuaian untuk masing-masing model pembayaran tersebut dengan kondisi di Indonesia.
\end{abstract}

Kata Kunci: e-payment, $B 2 C$, e-commerce

\begin{abstract}
Nowadays, the development of e-commerce applications in Indonesia, especially the application for B2C (Business to Consumer) is increasing. An important component in the process of online buying and selling is the electronic payment (e-payment). This research aims to develop four models of electronic payments based on economic conditions, safety, education level, access to technology, cell phone users, and credit cards and ATMs users in Indonesia. The payment model is ATMPal, iCash, Toll E-payment, and Mobile Banking. Moreover, this research will determined to rank the suitability of each such payment model to the conditions in Indonesia.
\end{abstract}

Keywords: e-payment, $B 2 C$, e-commerce

\section{Pendahuluan}

Peningkatan perkembangan penggunaan internet di Indonesia dibarengi dengan peningkatkan aplikasi e-commerce khususnya aplikasi B2C (Business to Consumer) dalam melakukan proses penjualan dan pembelian secara online. Salah satu aplikasi B2C yang sukses dan populer saat ini adalah Amazon.com yang merupakan toko buku online terbesar di dunia. Komponen penting dalam aplikasi B2C adalah $e$ payment yang digunakan untuk transfer uang secara elektronik antar pihak, seperti transfer dari konsumen ke penjual (B2C) atau antar personel (Peer to Peer atau P2P). E-payment menawarkan berbagai macam keuntungan seperti mempercepat proses transaksi dan dapat menjual produk dengan harga lebih murah. Pihak yang terlibat dalam proses transaksi dapat mentransfer dan menerima uang dari pihak lain kapanpun dan dimanapun. Disamping itu, e-payment juga dapat mendukung gerakan green technology dimana pemakaian kertas dapat dikurangi.
Terdapat beberapa faktor kesuksesan dalam $e$ payment yaitu: (a) Independence: metode $e$ payment yang tidak tergantung pada teknologi atau alat apapun; (b) Interoperability dan portability: aplikasi e-payment yang bisa diakses melalui berbagai macam teknologi dan platform; (c) Security: aplikasi e-payment harus memiliki tingkat keamanan yang baik seperti menggunakan Public Key Infrastructure (PKI), digital signature, dan lain sebagainya; (d) Anonymity: aplikasi $e$ payment dapat mendukung kerahasiaan data pribadi pengguna; (e) Ease of use: aplikasi $e$ payment harus dapat dengan mudah digunakan oleh pengguna; (f) Transaction fees: mekanisme pembagian keuntungan antar pihak yang terlibat dalam e-payment, dan ; (g) Regulacy: aplikasi $e$ payment harus dapat memenuhi peraturan yang berlaku.

Dalam pengeksekusian e-payment, terdapat empat pihak yang terlibat yaitu issuer, konsumen, penjual, dan regulator (pemerintah). Terdapat beberapa metode dalam pembagian keuntungan antar pihak yang terlibat di e-payment seperti 
biaya transaksi, biaya iklan, biaya registrasi, dan lain sebagainya. Sedangkan kondisi yang terkait dengan penggunaan e-payment di Indonesia adalah sebagai berikut:

\section{Kondisi ekonomi}

Semakin tinggi tingkat kesejahteraan dan tingkat pendidikan masyarakat, semakin tinggi pula akses mereka terhadap teknologi, serta semakin tinggi pula jumlah pilihan masyakarat dalam melakukan pembayaran. Namun, jumlah angkatan kerja Indonesia yang telah bekerja dan memiliki tingkat pendidikan SMA atau lebih tinggi hanya $26 \%$ saja [1]. Hal ini menunjukkan bahwa masyarakat Indonesia yang memiliki kesejahteraan dan akses teknologi yang baik hanya sedikit.

\section{Kondisi keamanan}

Menurut Brigjen Anton Taba, Staf Ahli Kapolri, Indonesia menduduki peringkat tertinggi dalam urusan kejahatan cyber [2]. Hal ini membuat kurangnya kepercayaan dari penyedia layanan $e$ payment untuk memberikan layanannya di Indonesia secara penuh.

\section{Kondisi tingkat pendidikan}

Rata-rata penduduk Indonesia yang memiliki pendidikan mengenyam pendidikan selama sebelas tahun, sementara negara-negara maju ratarata lebih dari tiga belas tahun. Jepang memiliki angka lima belas tahun, sedangkan Amerika Serikat, Inggris, Italia, memiliki angka enam belas tahun. Berdasarkan data tersebut dapat disimpulkan bahwa tingkat pendidikan Indonesia masih cukup tertinggal dibandingkan negaranegara lain.

Kondisi akses teknologi

Akses terhadap teknologi juga menjadi hambatan, sebagai contoh dibandingkan jumlah seluruh masyarakat Indonesia, masyarakat Indonesia yang memiliki komputer hingga pertengahan 2006 baru berjumlah 6 juta unit [3]. Sedangkan jumlah pengguna internet di Indonesia hingga tahun 2008 diperkirakan baru mencapai 50 juta orang [4]. Kondisi tersebut menggambarkan bahwa kurang dari seperempat populasi Indonesia yang memiliki akses internet.

Kondisi pengguna telepon seluler

Jumlah pengguna telepon seluler di Indonesia jauh melebihi jumlah pengguna internet. Menurut Presiden Direktur PT Natrindo Telepon Seluler (NTS), Erik Aas, pada tahun 2009 jumlah pelanggan seluler adalah sekitar 117 juta orang. Pada tahun 2010, diperkirakan bertambah menjadi 131 juta [5]. Data ini menunjukkan bahwa separuh dari penduduk Indonesia memiliki akses telekomunikasi seluler.

Kondisi pengguna kartu kredit dan ATM

Walaupun pengguna kartu kredit di Indonesia diperkirakan sebesar 4-5 juta orang pada tahun 2008, jumlah pengguna kartu ATM/debit jauh lebih besar dibandingkan jumlah pengguna kartu kredit [6]. Pada tahun 2009, jumlah pengguna kartu ATM diperkirakan sebanyak 30-40 juta orang [7]. Artinya, popularitas penggunaan kartu ATM jauh melebihi penggunaan kartu kredit.

Dalam meningkatkan popularitas e-payment di Indonesia maka perlu dikembangkan suatu model yang sesuai dengan kondisi dan tren di Indonesia saat ini. Oleh sebab itu, objektif dari penelitian ini adalah: (1) Menawarkan alternatif model e-payment bagi masyarakat Indonesia yang disesuaikan dengan kondisi dan tren di Indonesia saat ini, dan (2) Mengembangkan prototipe model e-payment.

Saat ini, terdapat beberapa metode $e$ payment yang populer di dunia seperti pembayaran dengan menggunakan kartu kredit, kartu belanja (purchasing card), Electronic Funds Transfer (EFT), cek digital (e-check), uang elektronik (e-cash), micropayment, dompet elektronik (e-wallet), dan PayPal. Tahun 1950, kartu kredit mulai diperkenalkan namun penggunaannya baru banyak digunakan oleh masyarakat Indonesia beberapa tahun terakhir ini. Kekurangan dari sebagian besar kartu kredit adalah terdapat syarat transaksi minimum, sehingga tidak dapat mengatasi transaksi dalam jumlah kecil. Masalah ini dapat diatasi dengan $e$ micropayments yang dapat digunakan untuk transaksi jual beli skala kecil secara elektronik dengan maksimum transaksi 10 USD.

Tahun 2004, penggunaan cek digital meningkat $40 \%$ mencapai 968 juta transaksi. Selain itu, uang digital yang ekuivalen dengan uang kertas dan koin dapat digunakan dalam transaksi jual beli secara online. Keuntungan dari uang digital ini adalah konsumen dapat berbelanja lebih murah dan aman. Salah satu kelemahan dari model pembayaran yang sudah dijabarkan sebelumnya adalah konsumen harus berulang kali memasukkan data pribadinya setiap kali melakukan transaksi. E-wallet dapat digunakan untuk menyimpan data pribadi konsumen (misal nama dan alamat konsumen, nomor kartu kredit, dan lain sebagainya), sehingga memudahkan konsumen dalam melakukan transaksi dengan sekali menekan tombol klik konsumen dapat bertransaksi dan memunculkan data pribadinya. Salah satu model e-payment untuk organisasi adalah kartu belanja (purchasing card) dengan nilai minimum dan maksimum tertentu yang memiliki tujuan untuk memberikan kemudahan kepada pegawai di organisasi tersebut untuk membeli material, peralatan atau layanan yang diperlukan oleh organisasi. Selain itu, salah satu tipe pembayaran yang tidak menggunakan kartu adalah PayPal yang dapat mentransfer uang melalui internet. 


\section{Metodologi}

Penelitian ini telah menghasilkan empat model e-payment yang telah disesuaikan dengan kondisi Indonesia dan faktor-faktor kesuksesan dari e-payment. Model e-payment tersebut adalah ATMPal, ICash, Pulsa E-payment, dan mobile banking. Sub bab dibawah ini akan dijelaskan mengenai fitur-fitur yang ada, pihak yang terlibat, dan model pendapatan (revenue model) pada masing-masing model e-payment.

ATMPal, ide awal pengembangan ATMPal terinspirasi dari penggunaan PayPal Indonesia yang berbasis kartu kredit. Namun, di Indonesia masih sedikit masyarakat Indonesia yang menggunakan kartu kredit sebagai alat pembayaran. ATMPal dikembangkan untuk mengatasi masalah tersebut dimana pembayaran langsung di-autodebet pada rekening bank milik pengguna atau konsumen. ATMPal dapat memberikan kemudahan bagi pengguna dalam melakukan pembayaran secara online dengan mengintegrasikan antara bank dan ATMPal.

Pihak-pihak yang terlibat dalam ATMPal adalah pengguna ATMPal (end-users), bank pengguna, penyedia layanan ATMPal, dan penjual (merchant). Fitur yang terdapat di ATMPal adalah registrasi pengguna, transfer uang antara pengguna ATMPal dan bukan pengguna ATMPal, serta cek saldo akun pengguna. Fitur utama di ATMPal yaitu proses registrasi dan pembayaran dengan ATMPal.

Proses Registrasi

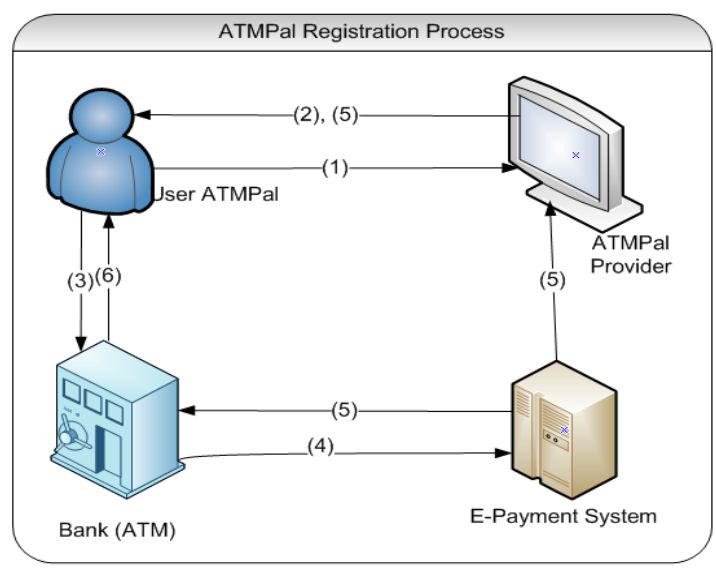

Gambar 1. Proses registrasi ATMPal.

Alur detil proses registrasi ATMPal (gambar 1) adalah sebagai berikut: (1) Pengguna mengakses website ATMPal dan melakukan proses registrasi dengan memasukkan email, nomor rekening yang dimiliki, nama bank dimana nomor rekening terdaftar, dan nama lengkap; (2) Pengguna mendapatkan kode aktivasi jika proses registrasi berhasil; (3) Pengguna melakukan aktivasi di ATM (Anjungan Tunai Mandiri) dengan memasukkan kode aktivasi; (4) Bank mengirimkan data kode aktivasi ke sistem $e$ payment untuk dilakukan pengecekan apakah kode aktivasi yang dimasukkan oleh pengguna valid atau tidak; (5) Jika proses validasi berhasil, sistem e-payment mengirimkan notifikasi keberhasilan proses aktivasi yang kemudian ditampilkan di ATM; dan (6) ATM memberikan notifikasi kepada pengguna jika nomor aktivasi telah berhasil diverifikasi.

Proses Pembayaran

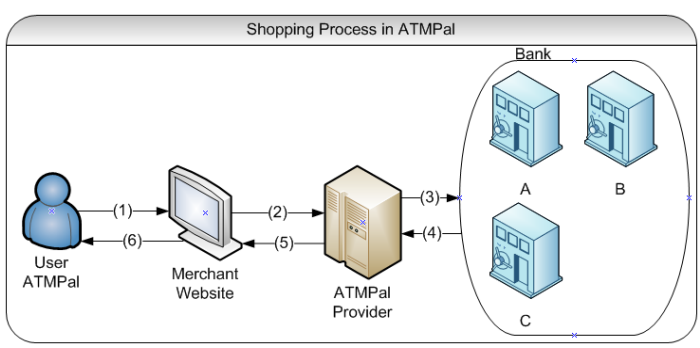

Gambar 2. Proses pembayaran ATMPal.

Penjelasan alur proses pembayaran ATMPal (gambar 2) adalah sebagai berikut: (1) Setelah pengguna memilih barang atau jasa yang akan dipesan dan melakukan check out, website merchant akan meminta pengguna untuk melakukan login; (2) Pada saat melakukan pembayaran, website merchant menampilkan halaman invoice dan pengguna diminta untuk memasukkan TAN (Transaction Authentication Number) number. TAN number merupakan suatu kode unik terdiri dari delapan digit yang dihasilkan oleh bank dan digunakan setiap kali nasabah melakukan transaksi keuangan di ATM. Setelah pengguna memasukkan TAN number, website merchant mengirimkan data-data transaksi ke sistem e-payment. Data-data transaksi tersebut terdiri dari nama merchant, nominal transaksi, barang-barang yang dibeli, dan TAN number yang dimasukkan oleh pengguna ATMPal. TAN number yang telah digunakan akan dihapus oleh bank dan tidak dapat digunakan lagi oleh nasabah yang bersangkutan. Bank akan memberikan TAN number setiap bulannya atau jika nasabah tersebut kehabisan TAN number. Tujuan digunakannya TAN number adalah sebagai bukti autentik bahwa nasabah yang melakukan transaksi keuangan adalah benar pemilik rekening tersebut dan bukan pihak lain yang tidak memiliki hak atas rekening tersebut; (3) Data-data transaksi tersebut dikirim ke pihak bank dan disesuaikan dengan rekening yang digunakan oleh pengguna. Pihak bank kemudian mengurangi saldo rekening milik pengguna 
sebesar nominal transaksi pembelian dan memindahkan saldo tersebut ke rekening yang digunakan oleh pihak penyedia layanan $e$ payment; (4) Pihak bank memberitahukan keberhasilan transaksi pembelian ke sistem $e$ payment dan sistem e-payment menyimpan data transaksi; (5) Sistem e-payment mengirimkan data dan status keberhasilan transaksi ke website merchant yang kemudian disimpan oleh merchant. Digital signature dari pengguna disisipkan ke informasi keberhasilan transaksi milik merchant; (6) Website merchant memperlihatkan informasi mengenai keberhasilan transaksi kepada pengguna. Digital signature dari merchant disisipkan ke informasi keberhasilan transaksi milik pengguna.

Model pendapatan dari ATMPal tergantung dari perjanjian komersial antar pihak yang terlibat. Model pendapatan di ATMPal bisa menggunakan variable transaction fee yang besarnya tergantung dari besarnya nilai transaksi misalkan 5\% dari jumlah total transaksi. Model pendapatan lainnya yang dapat digunakan di ATMPal adalah fix transaction fee contohnya $\mathrm{Rp} 5.000$ yang diberikan per transaksi.

iCash. Model iCash terinspirasi dari sistem pembayaran pada pulsa telepon seluler. Tujuan dikembangkannya iCash adalah memudahkan pengguna untuk melakukan penyimpanan uang dan melakukan pembayaran online tanpa harus melalui rekening di bank. Keuntungan dari iCash adalah pengguna dapat membayar barang atau jasa yang dibeli secara online, proses pengisian saldo dapat dilakukan dengan mudah yaitu melalui ATM atau voucher serta pengguna dapat mentransfer uang ke pihak lain. Pihak-pihak yang terlibat dalam iCash adalah pengguna iCash, penyedia layanan iCash, dan penjual.

Pengisian Saldo dengan Menggunakan Voucher

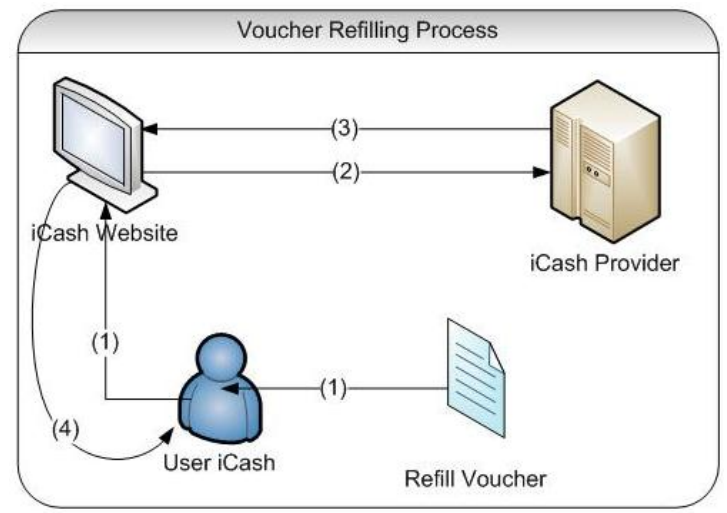

Gambar 3. Proses pengisian saldo dengan voucher.

Gambar 3 menjelaskan aliran proses pengisian saldo dengan menggunakan voucher:
(1) Pengguna membeli voucher iCash pada distributor voucher; (2) Pengguna mengakses website iCash dan memasukkan kode unik yang tertera pada voucher (proses ini dilakukan dengan asumsi pengguna iCash telah memiliki akun dan berhasil melakukan proses login); (3) Website $e$ payment mengirimkan data kode voucher ke sistem e-payment untuk dilakukan proses validasi. Jika kode voucher yang dimasukkan oleh pengguna merupakan kode voucher yang valid, maka sistem e-payment akan meningkatkan saldo pengguna sebesar nominal yang tertera pada voucher; dan (4) Sistem e-payment mengirimkan informasi besarnya saldo pengguna iCash yang telah mengalami pengaktualisasian (update).

Pengisian Saldo iCash dengan Menggunakan ATM

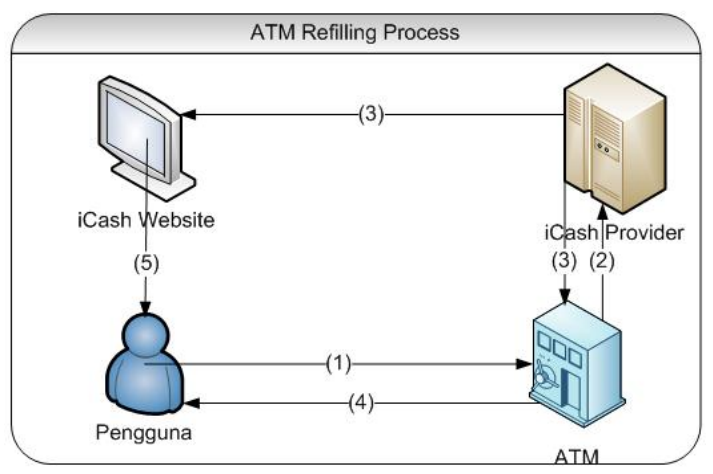

Gambar 4. Proses pengisian saldo iCash melalui ATM.

Selain melalui voucher, pengguna juga dapat melakukan pengisian saldo melalui ATM (gambar 4) dengan aliran proses sebagai berikut: (1) Pengguna mengakses ATM dan memilih menu pengisian saldo iCash serta memasukkan nomor akun iCash; (2) ATM/bank menginformasikan penyedia layanan iCash bahwa pengguna akan melakukan pengisian salso iCash; (3) Penyedia layanan iCash mengaktualisasi saldo pengguna dan memberikan informasi ke bank. Penyedia layanan iCash juga mengirimkan notifikasi ke pengguna mengenai status proses pengisian saldo melalui website iCash; (4) ATM menujukkan notifikasi suksesnya pengisian saldo; dan (5) Pengguna dapat melihat notifikasi dari penyedia layanan iCash di website iCash.

Proses Transaksi dan Pembayaran

Alur proses transaksi dan pembayaran di iCash adalah (gambar 5): (1) Pengguna melakukan transaksi di website merchant; (2) Merchant mengirimkan informasi transaksi pada penyedia layanan iCash. Penyedia layanan iCash menambah saldo merchant iCash dan mengurangi saldo pengguna iCash; (3) Penyedia layanan iCash mengirimkan notifikasi bahwa transaksi berhasil dilakukan ke website merchant dan 
pengguna iCash; dan (4) Pengguna dapat melihat notifikasi tersebut di website merchant.

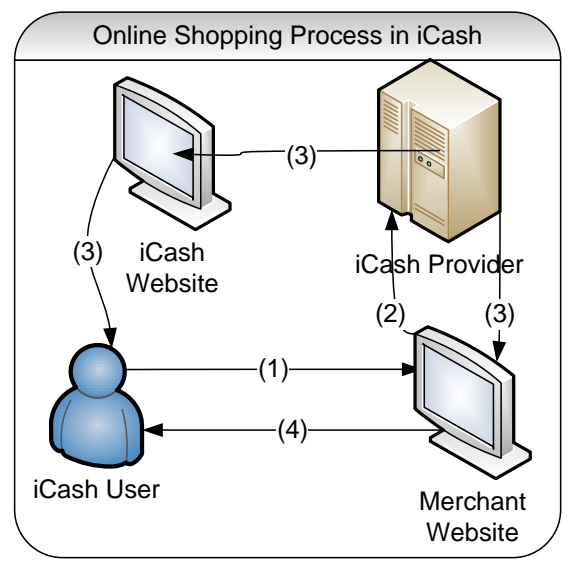

Gambar 5. Proses transaksi dan pembayaran di iCash.

Revenue model yang diterapkan pada penyedia layanan iCash adalah variable transaction fee dan revenue model yang diterapkan pada merchant berdasarkan pada banyaknya barang atau jasa yang berhasil terjual.

Pulsa E-payment. Ide dasar dari model Pulsa E-payment adalah menggunakan pulsa ponsel sebagai pengganti uang untuk alat pembayaran. Ide ini lahir didorong oleh banyaknya pengguna ponsel yang ada di Indonesia. Menurut peraturan yang dibuat oleh Bank Indonesia (BI) hal ini diperbolehkan dengan merujuk pada Peraturan Bank Indonesia nomor 7/52/PBI/2005 pasal 6 ayat 3. Pihak yang terlibat dalam model Pulsa $E$ payment adalah pengguna Pulsa E-payment, operator seluler, merchant, bank, dan penyedia layanan Pulsa E-payment. Pulsa E-payment memiliki tiga fitur seperti fitur untuk melakukan transaksi jual beli, pengisian, dan pengiriman pulsa. Fokus dari model Pulsa E-payment adalah pada fitur transaksi jual beli melalui handphone.

Berdasarkan gambar 6, alur yang terjadi ketika pengguna Pulsa E-payment melakukan transaksi jual beli adalah sebagai berikut: (1) Pengguna memanggil nomor sistem e-payment; (2) Operator meminta menu pembelian dari sistem e-payment; (3) Sistem e-payment mengirim data menu pembelian ke operator; (4) Operator mengirim service message yang berisi menumenu pembelian; (5) Pengguna mengakses menumenu yang sesuai dengan kebutuhannya (2), (3), (4), dan (5) berulang terus hingga pengguna memilih menu yang akan dilakukan, atau tidak memilih (keluar); (6) Operator seluler mengirimkan pesan kepada sistem e-payment mengenai menu pembelian yang dipilih pengguna; (7) Sistem e-payment memberi tahu merchant bahwa uang sejumlah transaksi pembelian dari pengguna telah dikirimkan ke rekening merchant dan sekaligus mengurangi saldo pengguna; (8) Merchant memberikan notifikasi kepada penyedia layanan pulsa e-payment bahwa transaksi telah berhasil disimpan; dan (9) Sistem e-payment memberitahu pengguna dan operator seluler apakah transaksi gagal atau berhasil.

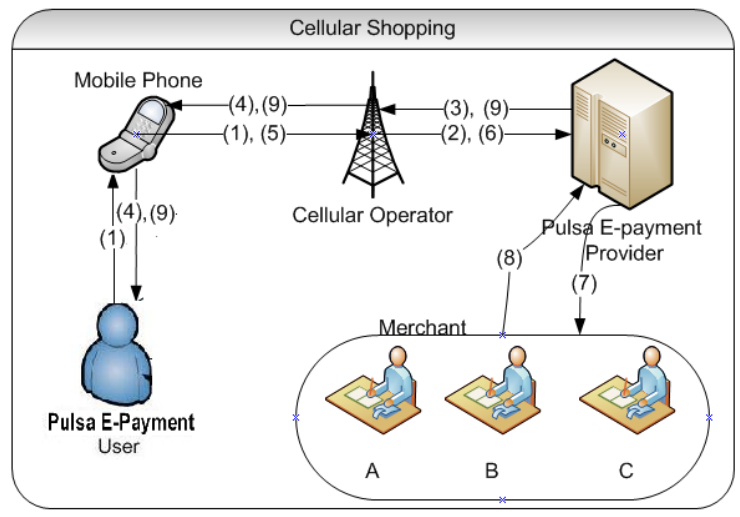

Gambar 6. Proses transaksi jual beli menggunakan Pulsa Epayment.

Revenue model yang diterapkan pada penyedia layanan Pulsa E-payment adalah variable transaction fee, pada merchant berdasarkan banyaknya barang atau jasa yang berhasil terjual, dan pada operator seluler adalah fix transaction fee. Hal yang perlu diperhatikan pada proses pembelian melalui Pulsa E-payment ini adalah nominal nilai transaksinya terbatas.

Mobile Banking. Sebagian besar masyarakat Indonesia menggunakan kartu ATM untuk berbelanja maupun mengakses akun bank mereka melalui mesin ATM. Pengaksesan akun bank melalui ATM walaupun mudah dilakukan namun masih memiliki beberapa kelemahan yaitu pengguna masih harus pergi ke mesin ATM untuk melakukan transaksi. Untuk memecahkan masalah ini, pada penelitian ini dirancang model Mobile Banking yang dapat digunakan untuk mengakses akun bank melalui handphone sehingga pengguna dapat mengakses akunnya dari manapun dan kapanpun.

Ide awal dari model ini adalah pengintegrasian akun bank pengguna dan handphone pengguna. Tujuan dari pengembangan Mobile Banking adalah untuk memberikan kemudahan bagi pengguna untuk mentransfer uang mereka dan melakukan pembayaran melalui handphone. Terdapat lima pihak yang terlibat dalam model ini yaitu pengguna, operator seluler, bank, penyedia layanan Mobile Banking, dan merchant. Mobile Banking memiliki fitur registrasi, melihat saldo akun, transfer saldo, purchase order, dan pembayaran. 
Proses Registrasi

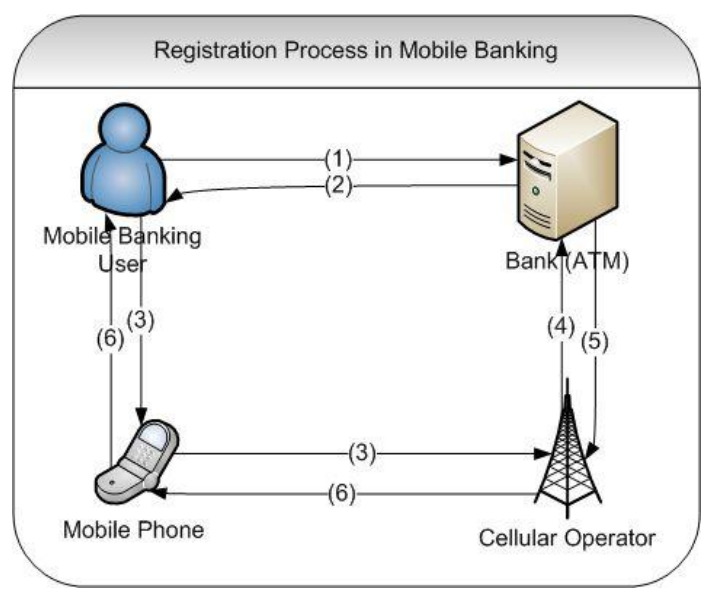

Gambar 7. Proses registrasi mobile banking.

Gambar 7 menjelaskan proses registrasi Mobile banking yaitu: (1) Pengguna akun bank mendaftarkan nomor handphone mereka di bank atau mesin ATM untuk layanan Mobile Banking; (2) Bank/ATM memberikan kode aktivasi ke pengguna yang berfungsi untuk memastikan bahwa nomor handphone yang teregistrasi benar dimiliki oleh pengguna; (3) Pengaktivasian nomor handphone dan akun bank pengguna untuk layanan Mobile Banking, pengguna harus mengirimkan pesan aktivasi yang berisi kode aktivasi melalui operator seluler; (4) Operator seluler kemudian memberikan informasi tersebut ke bank dan bank akan memproses informasi tersebut untuk mengaktivasi akun bank pengguna terhadap layanan Mobile banking; (5) Bank memberikan notifikasi ke operator seluler bahwa akun bank pengguna telah diaktivasi dan kemudian operator seluler juga mengaktivasi nomor handphone pengguna; dan (6) Operator seluler mengirim pesan ke pengguna bahwa aktivasi telah sukses dilakukan dan pengguna dapat mengakses akun bank mereka melalui handphone untuk berbelanja maupun transfer uang.

Membuat Purchase Order

Untuk membuat purchase order, pengguna harus mengisi terlebih dahulu formulir pembelian barang beserta data personal seperti nomor akun bank dan nama bank. Setelah dibentuk purchase order berdasarkan data tersebut, merchant akan membuat kode transaksi yang merupakan kode unik untuk setiap transaksi.

Proses Pembayaran

Gambar 8 menunjukkan proses pembayaran mobile banking setelah dibentuk purchase order dan kode transaksi. Langkah yang harus dilakukan pada proses pembayaran adalah: (1) Pengguna mobile banking mengirimkan pesan pembayaran yang berisi kode transaksi melalui SMS ke nomor penyedia layanan mobile banking; (2) Penyedia layanan mobile banking mengecek kode transaksi tersebut; (3) Penyedia layanan mobile banking memverifikasi kode transaksi ke merchant; (4) Merchant menginformasikan penyedia layanan mobile banking mengenai hasil validasi kode transaksi; (5) Jika kode transaksi valid maka penyedia layanan mobile banking akan mengirimkan informasi ke bank untuk mentransfer uang dari saldo akun pengguna ke merchant sesuai dengan data purchase order; (6) Bank mengonfirmasi ke penyedia layanan mobile banking jika transaksi pembayaran berhasil dilakukan; (7) Penyedia layanan mobile banking menginformasikan apakah transaksi berhasil dilakukan atau tidak ke pengguna melalui handphone dan merchant; (8) Merchant mengkonfirmasi informasi yang disampaikan oleh penyedia layanan Mobile banking; dan (9) Operator seluler menyampaikan informasi tentang transaksi pembayaran ke pengguna melalui SMS.

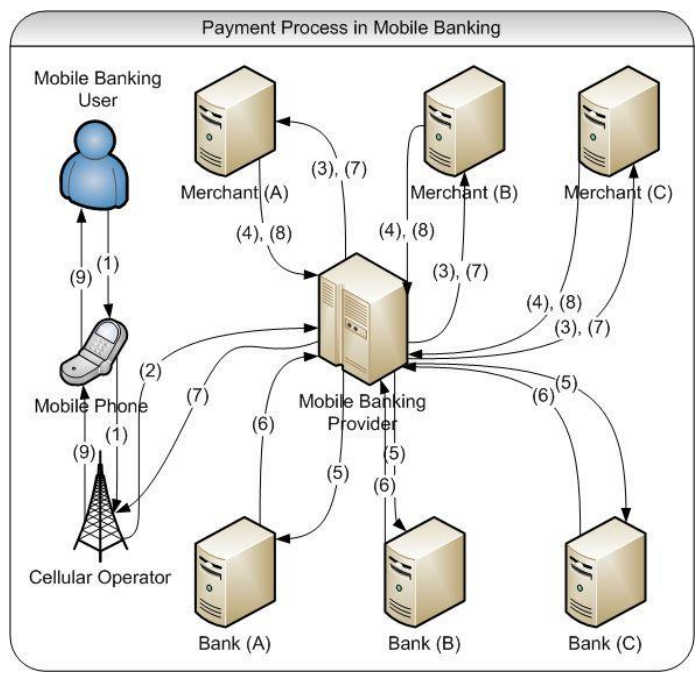

Gambar 8. Proses pembayaran mobile banking.

Model pendapatan yang dapat diimplementasikan pada model Mobile Banking dapat berupa sales margin dan fix atau variable transaction fee.

\section{Analisis dan Pembahasan}

Tujuan dari survei dan analisis data yang dilakukan adalah untuk mengetahui respon dari pengguna mengenai keempat model ini dilihat dari sudut pandang kemudahan, kenyamanan, dan keamanan. Model survei yang digunakan adalah survei berbasis web. Melalui survei berbasis web ini, responden melakukan skenario yang telah ditetapkan untuk masing-masing model sesuai dengan fitur yang dimiliki oleh tiap model dan 
pada model e-payment yang terakhir responden dapat mengisi kuesioner mengenai kemudahan, kenyaman, dan keamanan tiap model.

Pengolahan dan analisis data pada survei ini dilakukan dengan metode statistika deskriptif karena teknik sampling yang digunakan adalah convenience sampling. Analisis akan dilakukan terhadap data-data yang diperoleh dari proses survei yang telah dijalankan sebelumnya sehingga tidak dilakukan generalisasi atas hasil analisis tersebut terhadap populasi pengguna internet di Indonesia. Pengolahan statistika yang dilakukan adalah penghitungan nilai median dan nilai modus berdasarkan keseluruhan data mentah nilai yang diberikan oleh seluruh responden. Nilai median dan nilai modus itulah yang kemudian dipakai untuk menggambarkan kecenderungan responden terhadap model-model yang diujicobakan dalam survei. Survei berlangsung selama kurang lebih dua minggu, dimulai dari tanggal 19 Mei 2009 sampai dengan tanggal 2 Juni 2009. Total responden survei ini adalah 461 orang. Namun, dari jumlah tersebut hanya 53 orang yang menyelesaikan surveinya. Responden tersebut aktif dalam berbagai macam mailing list seperti informatika dan pendidikan.

Gambar 9 menunjukkan model ATMPal dan iCash memiliki nilai median yang sama dalam hal kemudahan penggunaan model tersebut. Dalam hal kenyamanan, seluruh model mempunyai nilai yang sama dengan 4. Sedangkan dalam hal keamanan, Mobile Banking mendapatkan nilai tertinggi yang sama dengan 4. Selain analisis median, dilakukan juga analisis nilai modus untuk setiap model (gambar 10).

Berdasarkan gambar 10, sebagian besar responden menilai kemudahan dari ATMPal, iCash, Pulsa E-payment, dan Mobile Banking sama dengan 5. Selain itu, sebagian besar responden menilai rendah kenyaman dari Pulsa $E$ payment. ATMPal mendapatkan nilai rendah untuk nilai keamanan.

\section{Kesimpulan}

Masyarakat Indonesia memiliki beberapa karakteristik yang harus disesuaikan untuk model e-payment sehingga dapat mudah diterima oleh masyarakat Indonesia. Oleh sebab itu, penelitian ini ditujukan untuk mencari alternatif model B2C e-payment yang sesuai dengan kondisi dan tren di Indonesia seperti ATMPal, iCash, Pulsa Epayment, and Mobile Banking. Penelitian lebih lanjut sangat diperlukan untuk mengimplementasikan sistem e-payment dengan melakukan analisis yang lebih mendalam pada aspek keamanan dikarenakan aspek keamanan merupakan komponen paling penting dalam $e$ payment.

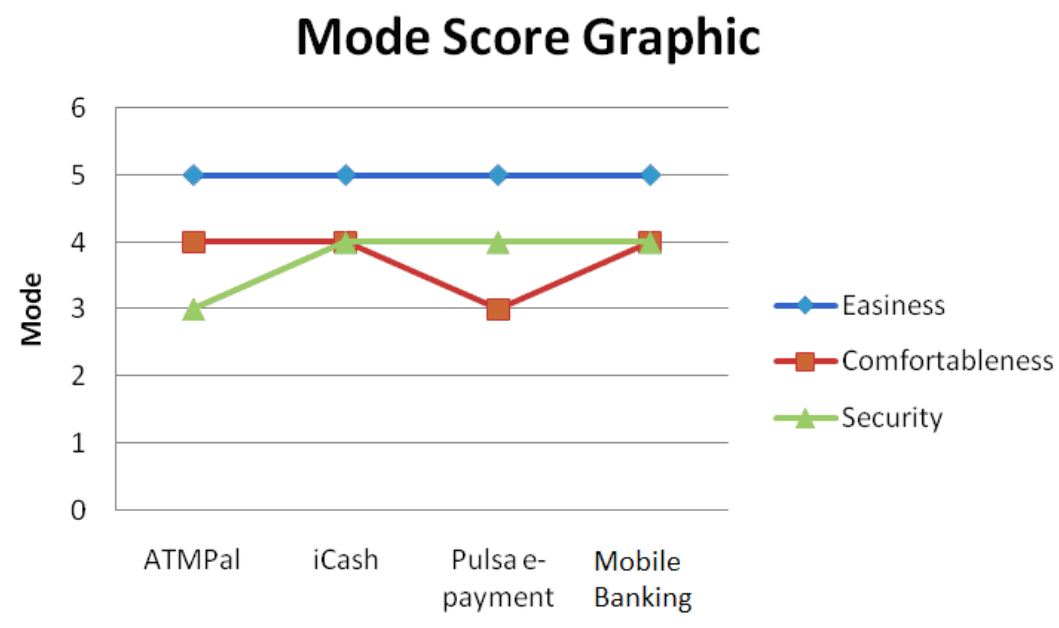

Gambar 9. Grafik median. 


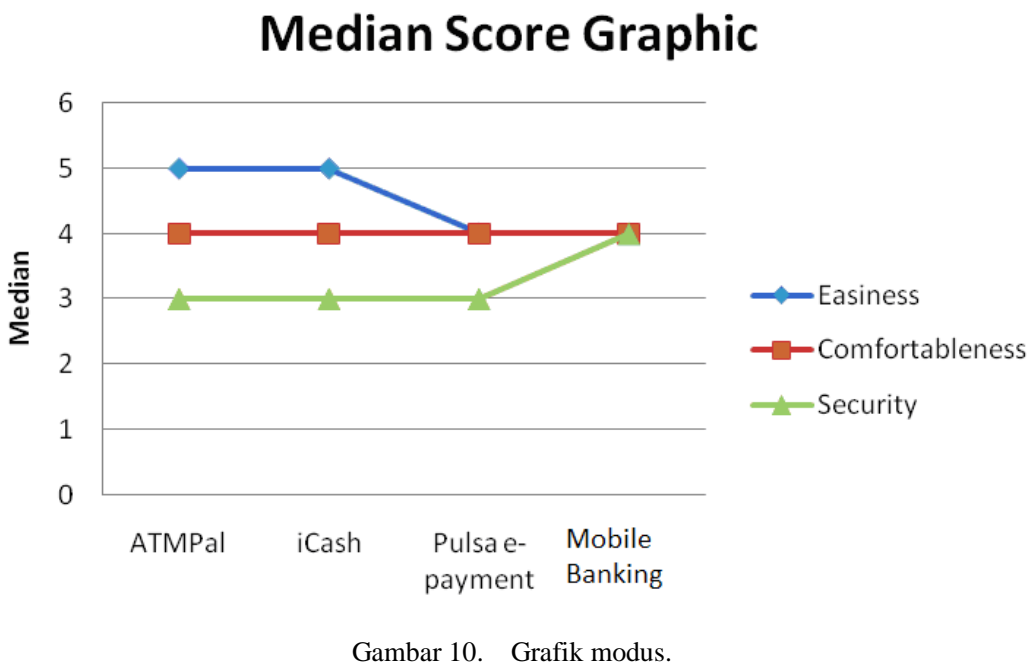

\section{Referensi}

[1] Badan Pusat Statistik, Perkembangan Beberapa Indikator Utama SosialEkonomi Indonesia, Indonesian Central Statistic Agency, Jakarta, 2009.

[2] A. Susanto, Cyber Crime Indonesia Tertinggi di Dunia, Kompas Article, http://internasional.kompas.com/read/xm 1/2009/03/25/18505497/cyber.crime.indo nesia.tertinggi.di.dunia, 2009, retrieved March 25, 2009.

[3] D. Partawidjaja, Mengejar Proyek Komputer di Daerah, in R. Mahendra, Gerakan Melek Teknologi Informasi Komunikasi untuk Meningkatkan ELiteracy di Indonesia, 2008.

[4] Kompas.com, Akhir Tahun Pengguna Internet 50 Juta, Kompas Tekno Article, http://tekno.kompas.com/read/xml/2008/ 06/10/01124884/akhir.tahun.pengguna.In ternet.50.juta, 2008, retrieved April 28,
2008.

[5] Rizagana, Outlook Telekomunikasi 2009 Berpacu Berebut Pelanggan Data, Perang Tarif Seluler Article, http://www.perangtarifseluler.com/index. php?option=com_content\&task=view\&i $\mathrm{d}=557 \&$ Itemid=61, 2008, retrieved June 17, 2008.

[6] Y. Karim, Kartu Kredit Tak Perlu Jadi Momok, Inilah.com Article, http://www.inilah.com/berita/ekonomi/20 08/03/11/16740/kartu-kredit-tak-perlujadi-momok, 2008, retrieved June 17, 2008.

[7] H. Purnomo, Penerapan Standar Nasional Kartu ATM dan Debet Dimulai, Detik Finance Article, http://www.detikfinance.com/read/2009/ 02/06/112158/1080502/5/penerapanstandar-nasional-kartu-atm-dan-debetdimulai, 2009, retrieved June 17, 2009. 